\title{
Data on the distribution of Dolichopodidae (Diptera: Empidoidea) in Bulgaria, with first records for the country
}

\author{
Mihail Kechev \\ Forest Research Institute, Bulgarian Academy of Sciences, 132 St Kliment Ohridski Blvd, Sofia, Bulgaria, \\ mkechev@gmail.com; https://orcid.org/0000-0002-9852-5184
}

\begin{abstract}
The paper presents information about 37 dolichopodid species, collected from 14 localities in Bulgaria. Five species (Medetera murina, Systenus scholtzi, Neurigona nubifera, Rhaphium antennatum and Sciapus bellus) are recorded for the first time for the fauna of Bulgaria. The species $S$. scholtzi is new to the Balkan Peninsula and the genus Systenus is a new genus of the family Dolichopodidae for the Bulgarian fauna.
\end{abstract}

Keywords: Bulgaria, Dolichopodidae, fauna, new records

\section{Introduction}

The family Dolichopodidae encompasses small- to middle-sized species (1 to $10 \mathrm{~mm}$ ). The flies of the family, also called long-legged flies, are predators and among their food sources are small invertebrates as ticks, insects (imago and larvae), worms and etc. The adults dwell in humid habitats around rivers, ponds, marshes, lakes and sea shores and rocks, and are also found in deciduous and coniferous forests. Their body is most often metallic-green but in some species could be yellow or blue. About 8000 different species are described worldwide, excluding Antarctica. In Bulgaria, 204 species are known up to now (Kechev et al., 2020; Kechev \& Glogov, 2021; Kechev, 2021).

The main purpose of this paper is to provide new records of the family Dolichopodidae for Bulgaria and data on the distribution of the dolichopodids in poorlystudied areas in the country.

\section{Material and methods}

The material for the present work was collected from 12 localities in Bulgaria (Fig. 1) using Malaise traps, two types of emergency traps (tree and soil traps) and sweep nets. The species were separated in the laborat- ory using a Carl Zeiss microscope. For the determination of dolichopodids were used publications by Parent (1938), Negrobov and Stackelberg (1969), d'Assis Fonseca (1978), Grichanov (2007) and Negrobov \& Naglis (2016). The species new to Bulgaria are marked with one asterisk (*) and the new one for the Balkan Peninsula with two asterisks (**) in front of the names. The material presented in this paper is housed in Mihail Kechev's collection in the Forest Research Institute, Bulgarian Academy of Sciences, Department of Forest Entomology, Phytopathology and Game Fauna, Sofia, Bulgaria.

\section{Sites of collecting}

Site 1: Granichar Village, $43.7230^{\circ} \mathrm{N} 28.4992^{\circ} \mathrm{E}, 48 \mathrm{~m}$, Malaise trap, N. Karaivanov.

1a: 11.VI-8.VII.2011.

1b: 8-28.VII.2011.

Site 2: Povelyanovo Village, $43.2228^{\circ} \mathrm{N} 27.6679^{\circ} \mathrm{E}$, 172 m, 28.VII.2020, sweep net, M. Kechev.

Site 3: Trabach Village, $43.3796^{\circ} \mathrm{N} 26.4962^{\circ} \mathrm{E}, 230 \mathrm{~m}$, Malaise trap, K. Ivanov.

3a: 8.VIII-22.IX.1999.

3b: 6-19.IX.1999.

Site 4: Samovodene Village, $43.1469^{\circ} \mathrm{N} 25.6155^{\circ} \mathrm{E}$, 108 m, 29.V-27.IV.2011, Malaise trap, E. Sarov. 


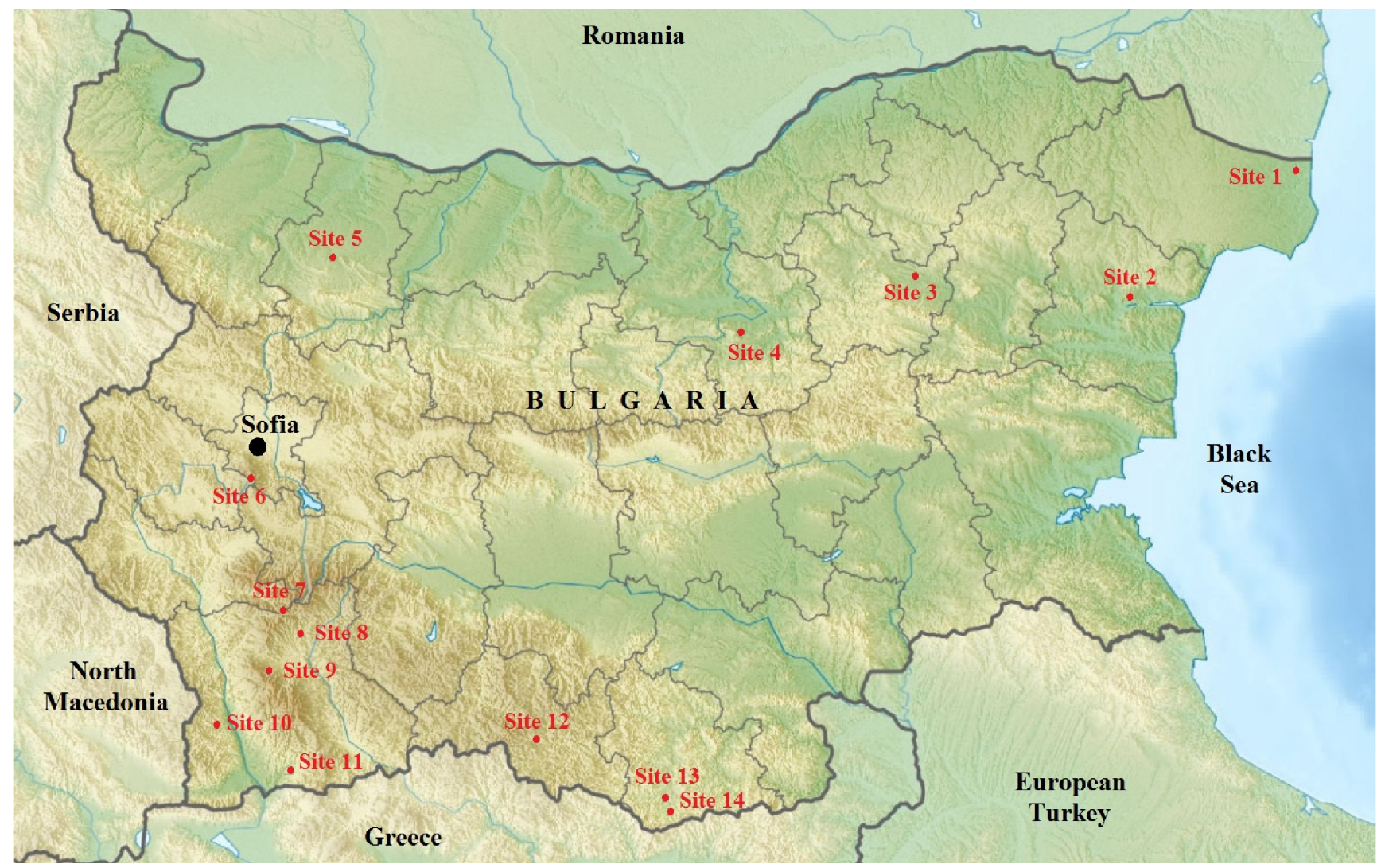

Fig. 1. Map of Bulgaria with sites of collection.

Site 5: Banitsa Village, $43.3450^{\circ} \mathrm{N} 23.6913^{\circ} \mathrm{E}, 260 \mathrm{~m}$, Malaise trap, T. Ljubomirov.

5a: 1-15.VII.2013.

5b: 16-31.VIII.2013.

5c: 9-31.VII.2015.

Site 6: Vitosha Mt, Gurgulitsa riverside, $42.5207^{\circ} \mathrm{N}$ 23.3368 $\mathrm{E}, 1350 \mathrm{~m}, 17 . \mathrm{VII}-4$.VIII.2010, Malaise trap, T. Ljubomirov.

Site 7: Rila Mts, Ravnite Mochuri Place, above Dobarsko Village, tree traps, N. Simov.

7a: 15.VI-9.VII. 2004.

7b: 9.VII-18.VIII.2004.

Site 8: Banya Village, Glazne River, $41.8875^{\circ} \mathrm{N}$ $23.5271^{\circ} \mathrm{E}, 780 \mathrm{~m}, 5 . \mathrm{VI} .2021$, sweep net, M. Kechev.

Site 9: Pirin Mts, Banderitsa River, near Vihren Hut, 2014 m, 9.VII-18.VIII.2004, tree traps, N. Simov.

Site 10: Kamenitsa Village, Struma Valley, $41.6484^{\circ} \mathrm{N}$ $23.1580^{\circ} \mathrm{E}, 240 \mathrm{~m}, 3 . \mathrm{IV}-3 . \mathrm{V} .2003$, tree trap, leg. M. Langourov and S. Lazarov.

Site 11: Kalimantsi Village, Struma Valley, $41.4592^{\circ} \mathrm{N}$ $23.4795^{\circ} \mathrm{E}, 267 \mathrm{~m}, 3 . \mathrm{IV}-03 . \mathrm{V} .2003$, tree trap, leg. M. Langourov and S. Lazarov.
Site 12: above Smolyan (Fig. 7), $41.5612^{\circ} \mathrm{N}$ $24.6432^{\circ} \mathrm{E}, 1360 \mathrm{~m}, 10 . \mathrm{VI} .2021$, sweep net, M. Kechev.

Site 13: East Rhodope Mts, Dzherovo Village (Fig. 8), Kazalach River, $41.3187^{\circ} \mathrm{N} 25.3256^{\circ} \mathrm{E}, 354 \mathrm{~m}$, Malaise trap, M. Langourov and N. Simov.

13a: 11-20.V.2021.

13b: 20.V-1.VI.2021.

13c: 1.VI-11.VI.2021.

13d: 11.VI-21.VI.2021.

13e: 21.VI-5.VII.2021.

Site 14: East Rhodope Mts, Kremen Village (Fig. 9), near a small stream right tributary of the river Kazalach, $41.2757^{\circ} \mathrm{N} 25.3396^{\circ} \mathrm{E}, 473 \mathrm{~m}$, Malaise trap, M. Langourov and N. Simov.

14a: 11-20.V.2021.

14b: 20.V-1.VI.2021.

14c: 1.VI-11.VI.2021.

14d: 11.VI-21.VI.2021.

14e: 21.VI-5.VII.2021. 
Data on the distribution of Dolichopodidae in Bulgaria, with first records for the country

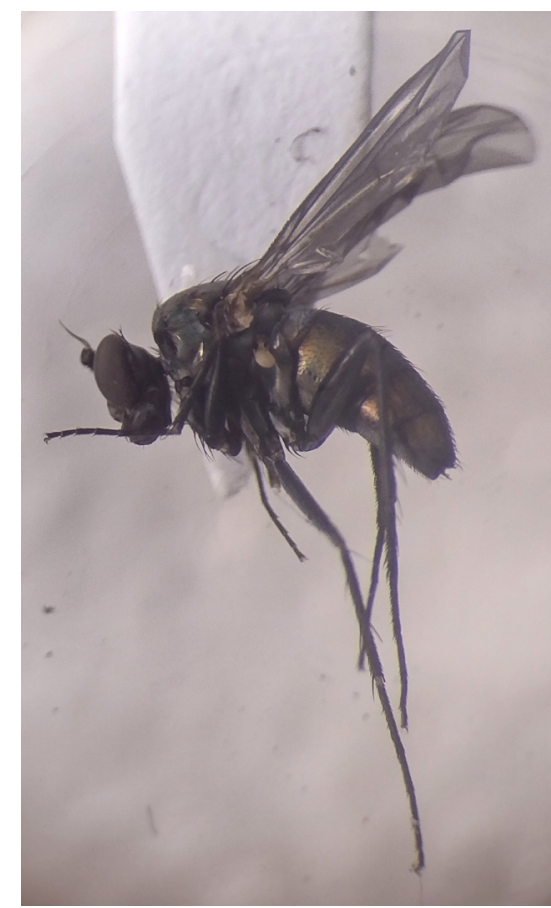

Fig. 2. Dolichopus picipes Meigen, 1824, female, habitus.

\section{Results}

Diaphorinae

Asyndetus latifrons (Loew, 1857) - Material examined: site 5c: $1 \hat{\jmath}$.

Chrysotus gramineus (Fallén, 1823) - Material examined: site $5 \mathrm{c}: 1$ $\widehat{\jmath}, 9$ 우.
Chrysotus laesus (Wiedemann, 1817) - Material

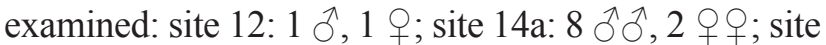
14b: 5 ふิ઼, 7 우.

Chrysotus suavis Loew, 1857 - Material examined: site $5 \mathrm{~b}: 1$ ㅊ, 6 우우.

Dolichopodinae

Dolichopus diadema Haliday, 1832 - Material examined: site 13a: 1 ô.

Dolichopus griseipennis Stannius, 1831 - Material

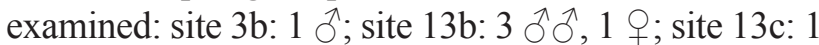
$\hat{\jmath}, 2$ 우; site 13d: $1 \hat{\jmath}, 2$ o 0 ; site 14c: $1 \hat{\jmath}$.

Dolichopus longitarsis Stannius, 1831 - Material examined: site 7b: $2 \hat{\jmath}, 1$ ○.

Dolichopus picipes Meigen, 1824 (Fig. 2) - Material examined: site 7a: 1 o; site 7b: 1 đ, 5 o 0 ; site 9: 1 o; site 12: 1 ㅇ.

Dolichopus plumipes (Scopoli, 1763) - Material examined: site 8: 1 ऽ̄.

Dolichopus popularis Wiedemann, 1817 (Fig. 3) Material examined: site 12: $1 \hat{\jmath}$.

Dolichopus ungulatus (Linnaeus, 1758) - Material

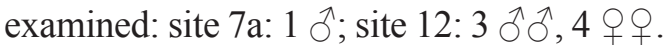

Gymnopternus aerosus (Fallén, 1823) - Material examined: site 12: 17 $\widehat{o}, 5$ o 9 .

Gymnopternus brevicornis (Staeger, 1842) - Ma-

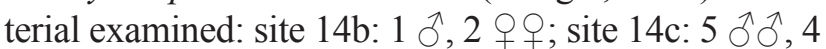
우; site 14d: 5 ふぇ, 9 우.

Gymnopternus celer (Meigen, 1824) - Material examined: site 14d: 1 त; site 14c: 1 त, 1 o.

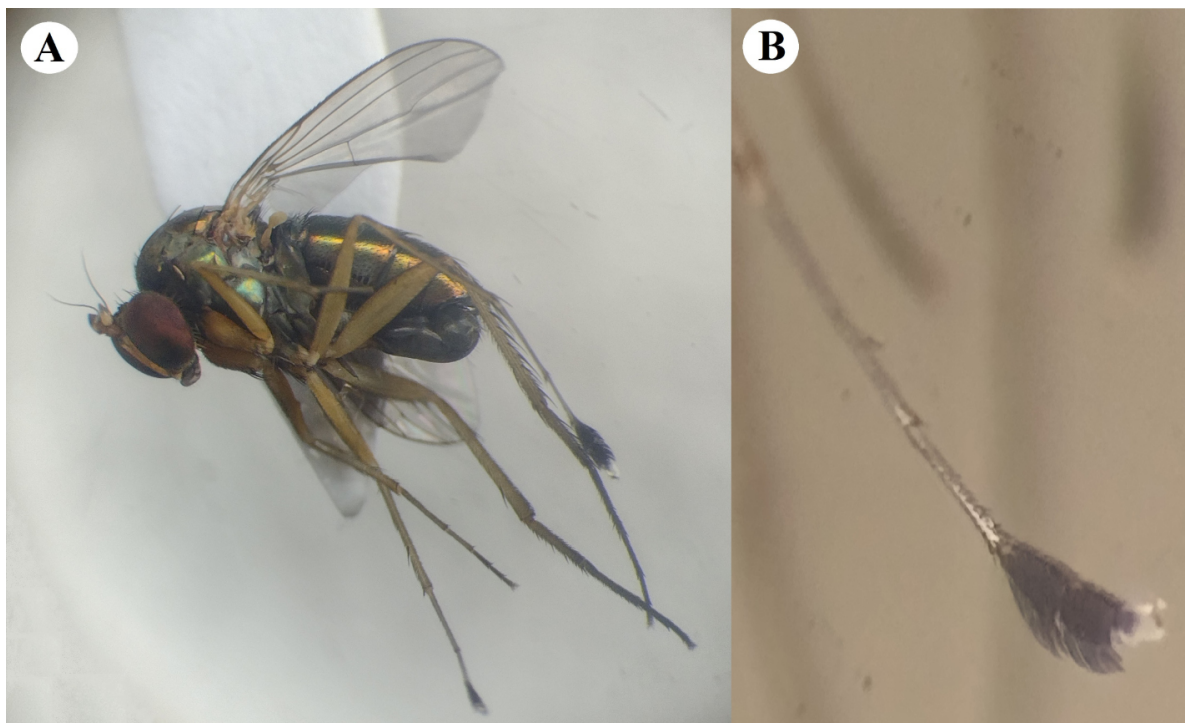

Fig. 3. Dolichopus popularis Wiedemann, 1817, male, A: habitus, B: mid tarsi. 


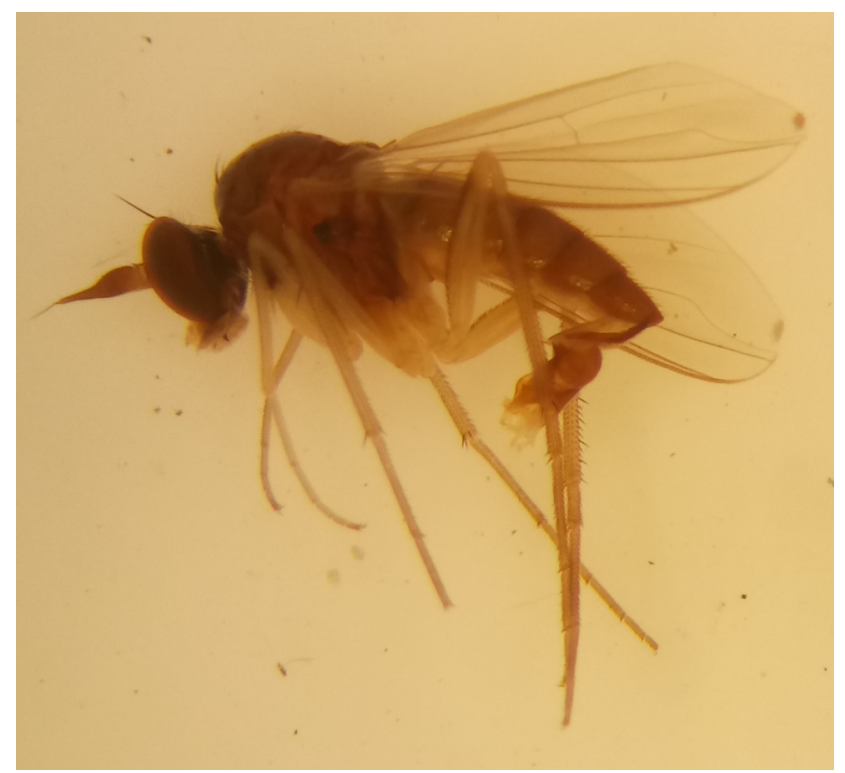

Fig. 4. Systenus scholtzi (Loew, 1850), male habitus.

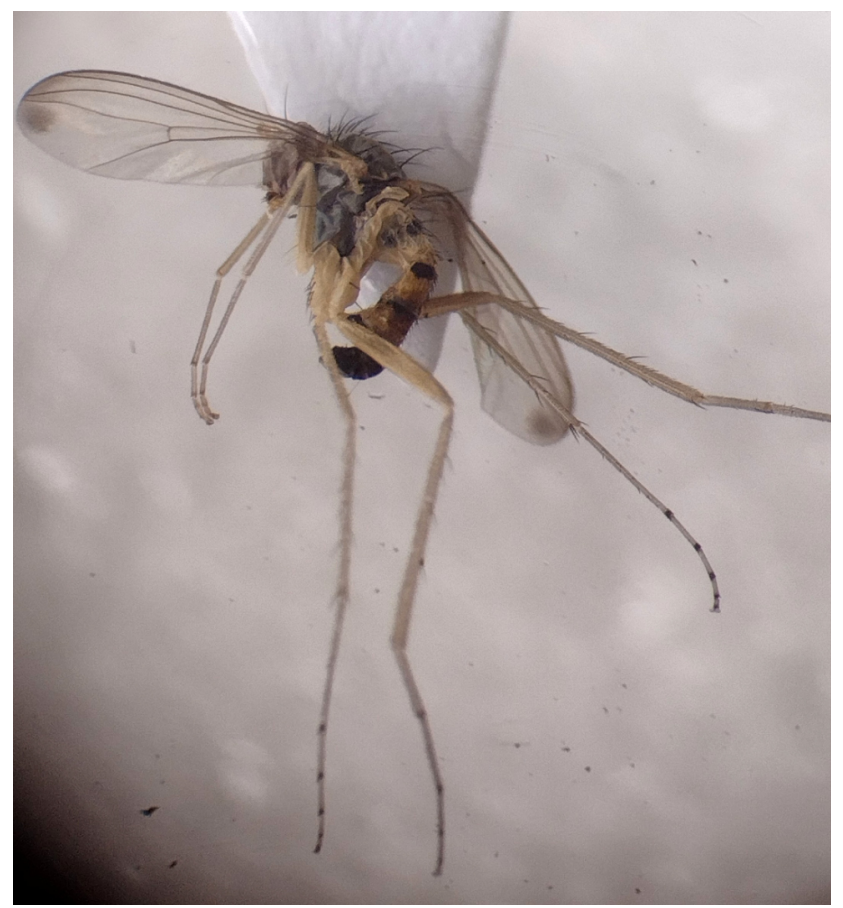

Fig. 5. Neurigona nubifera (Loew 1869), male habitus.

Hercostomus gracilis (Stannius, 1831) - Material examined: site 2: 6 ๙ิ઼, 2 우.

Hercostomus rusticus (Meigen, 1824) - Material examined: site 9: 1 ô.

Poecilobothrus chrysozygos (Wiedemann, 1817)Material examined: site 14e: 1 ô.
Poecilobothrus regalis (Meigen, 1824) - Material

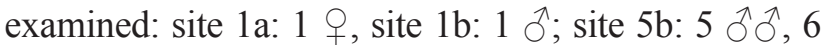
오.

Tachytrechus consobrinus (Haliday, 1851) - Material examined: site 14a: 1 ○.

\section{Medeteranae}

Medetera jacula (Fallén, 1823) - Material examined:

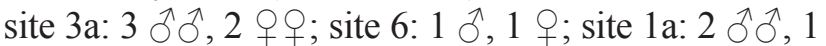

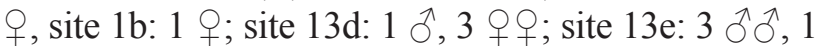
‥

Medetera micacea Loew, 1857 - Material ex-

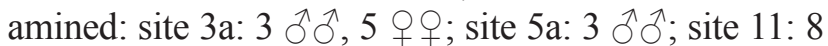
ふ̋̊, 7 우.

Medetera muralis Meigen, 1824 - Material examined: site 5a: $1 \hat{\jmath}$.

* Medetera murina Becker, 1917 - Material examined: site 4: $1 \hat{\jmath}$.

** Systenus scholtzi (Loew, 1850) (Fig. 4) - Material examined: site 11: 1 ऽ.

Hydrophorinae

Liancalus virens (Scopoli, 1763) - Material examined:

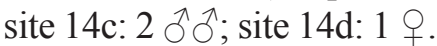

Neurigoninae

Neurigona pallida (Fallén, 1823) - Material examined:

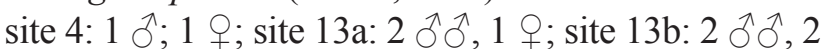
우; site 14c: 1 o; site $14 \mathrm{~d}: 1$ o ; site $14 \mathrm{e}: 1$ ㅇ.

* Neurigona nubifera (Loew 1869) (Fig. 5) - Material examined: site 13a: 38 ईิ), 27 oㅇ; site 13b: 2

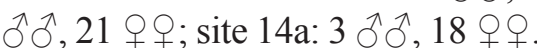

Neurigona suturalis (Fallén, 1823) - Material ex-

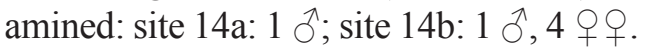

Peloropeodinae

Chrysotimus flaviventris (Roser, 1840) - Material examined: site 6: 1 $\widehat{\sigma}, 1$.

Rhaphiinae

* Rhaphium antennatum (Carlier, 1835) - Material ex-

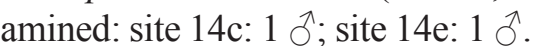

Rhaphium caliginosum (Meigen, 1824) - Material examined: site 5c: $1 \hat{\jmath}$. 


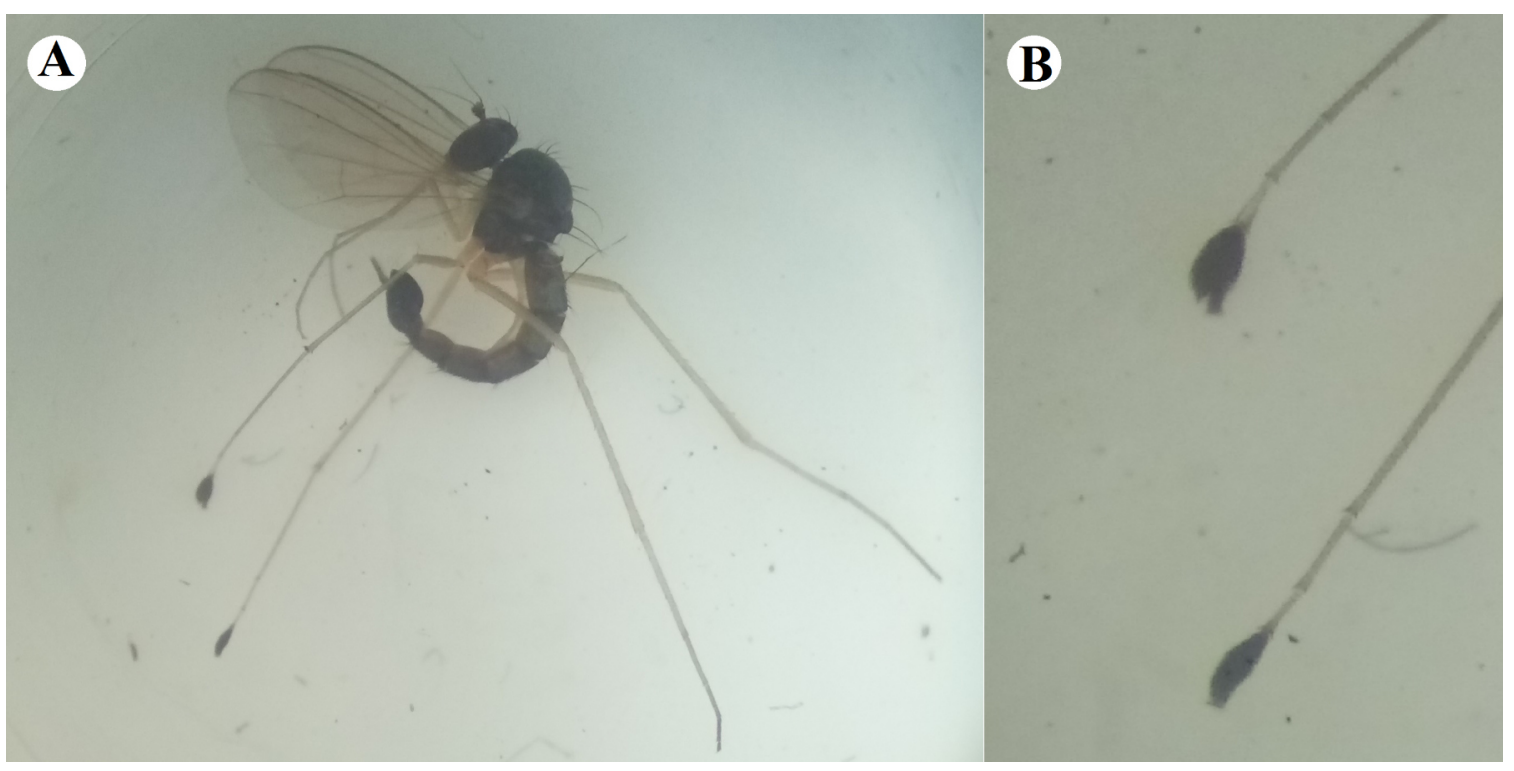

Fig. 6. Sciapus bellus Loew, 1873, male, A: habitus, B: mid tarsi.

Rhaphium laticorne (Fallén, 1823) - Material ex-

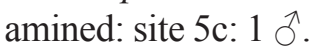

\section{Sciapodinae}

* Sciapus bellus Loew, 1873 (Fig. 6) - Material examined: site 6: 1 क; site 13a: $10 \hat{\jmath} \partial^{\lambda}, 3$ 우; site 13b: 2

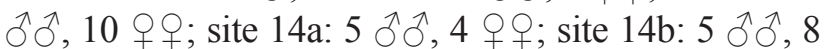
우아.

Sciapus flavicinctus (Loew, 1857) - Material ex-

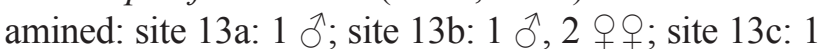
○; site 14a: 1 ठิ.

Sciapus platypterus (Fabricius, 1805) - Material examined: site 1a: 1 क ; site 4: 5 $\widehat{\partial}, 12$ 우 ; site $13 \mathrm{c}: 7$

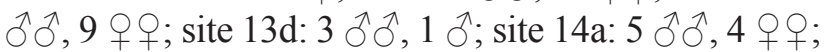

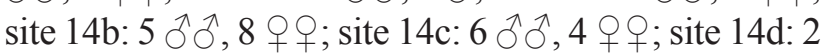

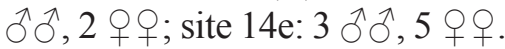

\section{Sympycninae}

Sympycnus pulicarius (Fallén, 1823) - Material examined: site 8: $6 \widehat{\jmath} \widehat{\partial}, 4$ 우.

Syntormon pallipes (Fabricius, 1794) - Material examined: site 8: 1 의 site 14e: 2 우, 1 우.

\section{Discussion}

Sciapus bellus, Neurigona nubifera, Rhaphium antennatum, Medetera murina and Systenus scholtzi are re- corded for the first time from Bulgaria. With these results the number of dolichopodids known for the Bulgarian fauna is increasing to 209 species. Systenus scholtzi is also new for the Balkan Peninsula. Systenus is presented with seven European species. Until now, two species have been known for the Balkan Peninsula; they were listed from Croatia: Kechev \& Ivanova (2015a), Pollet \& Ivković (2018) and Drake (2018) listed Systenus bipartitus (Loew, 1850), while Naglis (2017) described Systenus bartaki from Gornji Muć Village, near Split.

Three of the species listed in this paper (Neurigona nubifera, Sciapus bellus and S. platypterus) have been collected with a large number of specimens along riversides (sites 13 and 14, Figs 8 and 9). The single male specimen of $S$. bellus, mentioned above from the Vitosha Mt, has also been found along the riverside. Other reports of $S$. platypterus in Bulgaria are also mainly from river banks. This research suggests higher riparian affinity of these three species.

Dolichopus picipes, D. plumipes, D. popularis, D. ungulatus, Gymnopternus aerosus and Chrysotus laesus are found in great abundance in moist meadows surrounded by coniferous forests (Kechev, 2005, 2006 and 2010). Last two years Ch. laesus was found at lower altitudes in Bulgaria, along the banks of small brooks and rivers near the deciduous forest (Kechev, 2021)

Poecilobothrus regalis is one of the most common species in the lower parts of Bulgaria, from sea level up 

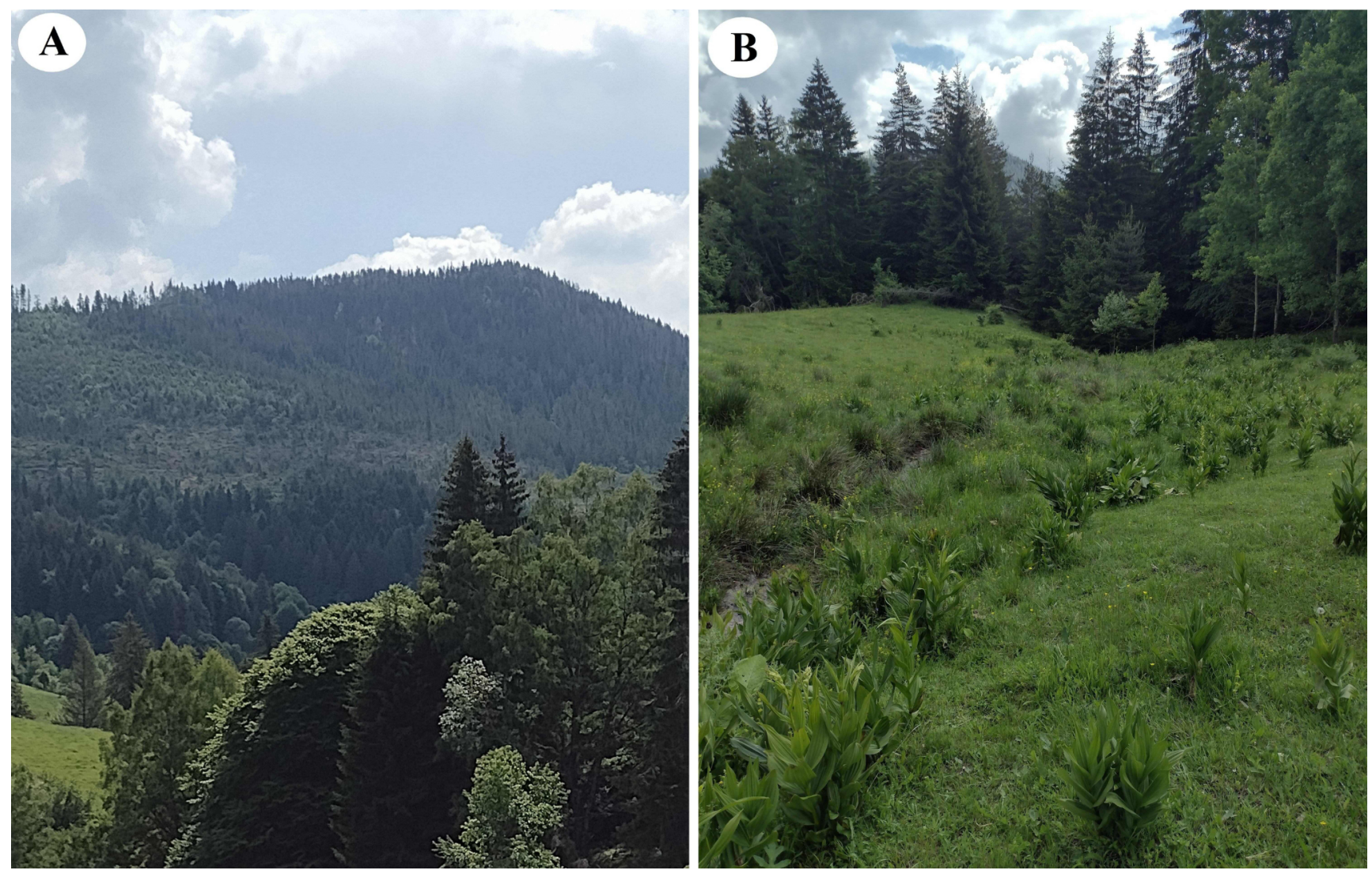

Fig. 7. Wet meadows in coniferous forests above the town of Smolyan, habitat of Dolichopus picipes, D. ungulatus, D. popularis, Gymnopternus aerosus and Chrysotus laesus.

to about $300 \mathrm{~m}$. It is reported mainly from southern Bulgaria, where it has been found with large numbers of specimens on river banks, ponds and marshes (Kechev \& Ivanova, 2015b, Kechev, 2019). Our study lists two new localities in northern Bulgaria.

Some regions in Bulgaria, including the Eastern Rhodope Mts, Pirin Mts, Rila Mts, Struma River Valley, are still not well studied in terms of their dolichopodid fauna. The southern parts of the E Rhodopes and the Struma River Valley are under the Mediterranean climatic influence. Future studies of these areas could results in the discovering of new species for the country and information on habitat preferences, and other ecological data for the family Dolichopodidae.

\section{Acknowledgements}

The author thanks Dr Mario Langourov and Dr Nikolay Simov from the National Museum of Natural History, Sofia and Dr Toshko Ljubomirov from the IBER, who provided me with material collected by them. Thanks are also due to N. Karaivanov, K. Ivanov, E. Savov and S. Lazarov for providing me with the material they had collected over the years. I express my gratitude to eng. Mitko Manev, director of the Southwest State Forestry Enterprise Kirkovo and the employees Stefan Kehayov and Sevdalin Rusenov for gathering of the material from the Malaise traps in Dzherovo and Kremen Villages. This work has been carried out in the framework of the National Science Program "Environmental Protection and Reduction of Risks of Adverse Events and Natural Disasters", approved by the Resolution of the Council of Ministers No. 577/ 17.08.2018 and supported by the Ministry of Education and Science (MES) of Bulgaria (Agreement No. D01-363/17.12.2020).

\section{References}

d'Assis Fonseca E.C.M. 1978 Diptera Orthorrhapha Brachycera. V. Dolichopodidae. Handbooks for the identification of British insects. IX. Part 5: 1-90. 
Data on the distribution of Dolichopodidae in Bulgaria, with first records for the country

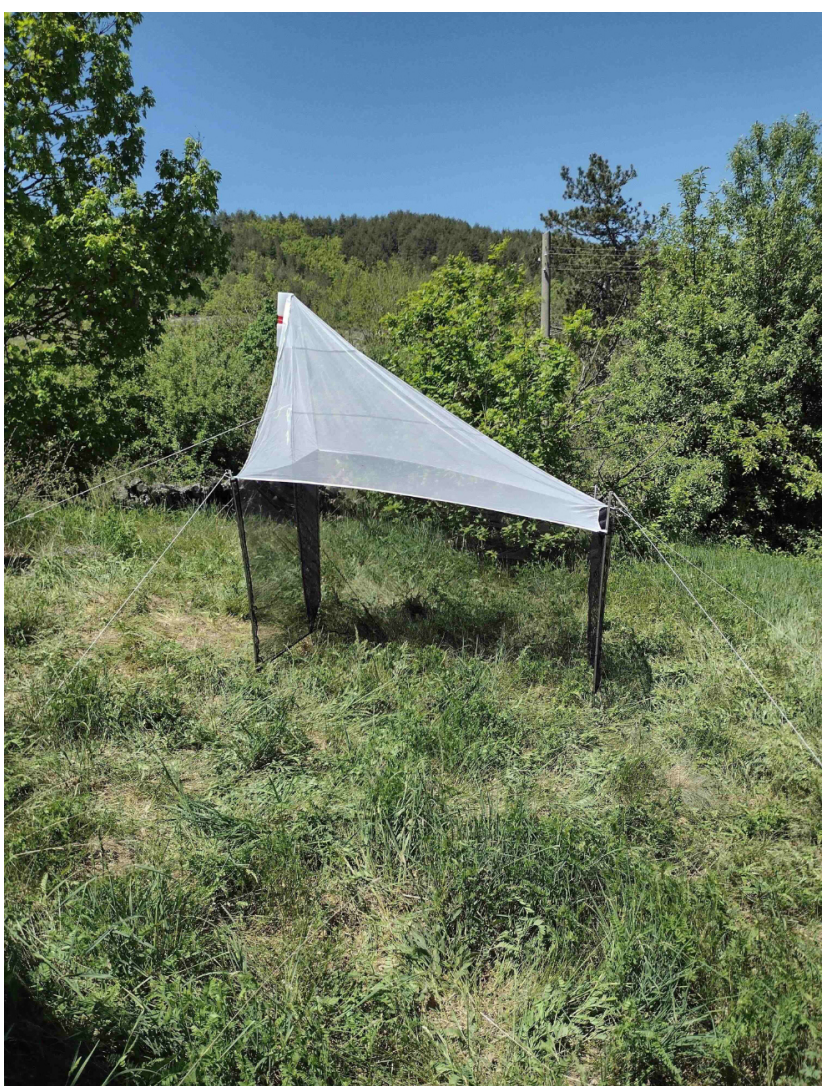

Fig. 8. Malaise trap on the bank of Kazalach River, near Dzherovo Village.

Drake C.M. 2018 A review of the status of the Dolichopodidae flies of Great Britain. Species Status No. 30. Natural England Commissioned Report NECR, 195, 1-174.

Grichanov I.Y. 2007 A checklist and keys to Dolichopodidae (Diptera) of the Caucasus and East Mediterranean. VIZR RAAS, Plant Protection News, St Petersburg, Supplement, pp. 1-160.

Kechev M. 2005 Check-list of Dolichopodidae (Diptera, Brachycera) species in Bulgaria. Animalia, Scientific Studies, University of Plovdiv 41: 47-62.

Kechev M. 2006 Dolichopodidae (Diptera, Brachycera) of the Western Rhodopes (Bulgaria). In: Beron, P. (ed.), Biodiversity of Bulgaria. 3. Biodiversity of Western Rhodopes (Bulgaria and Greece). I. Pensoft et Natural Museum of Natural History, Sofia, pp. 613-616.

Kechev M. 2010 New Dolichopodid flies (Diptera, Dolichopodidae) to the fauna of Bulgaria collected in the West Rhodopes (Bulgaria). Distribution and

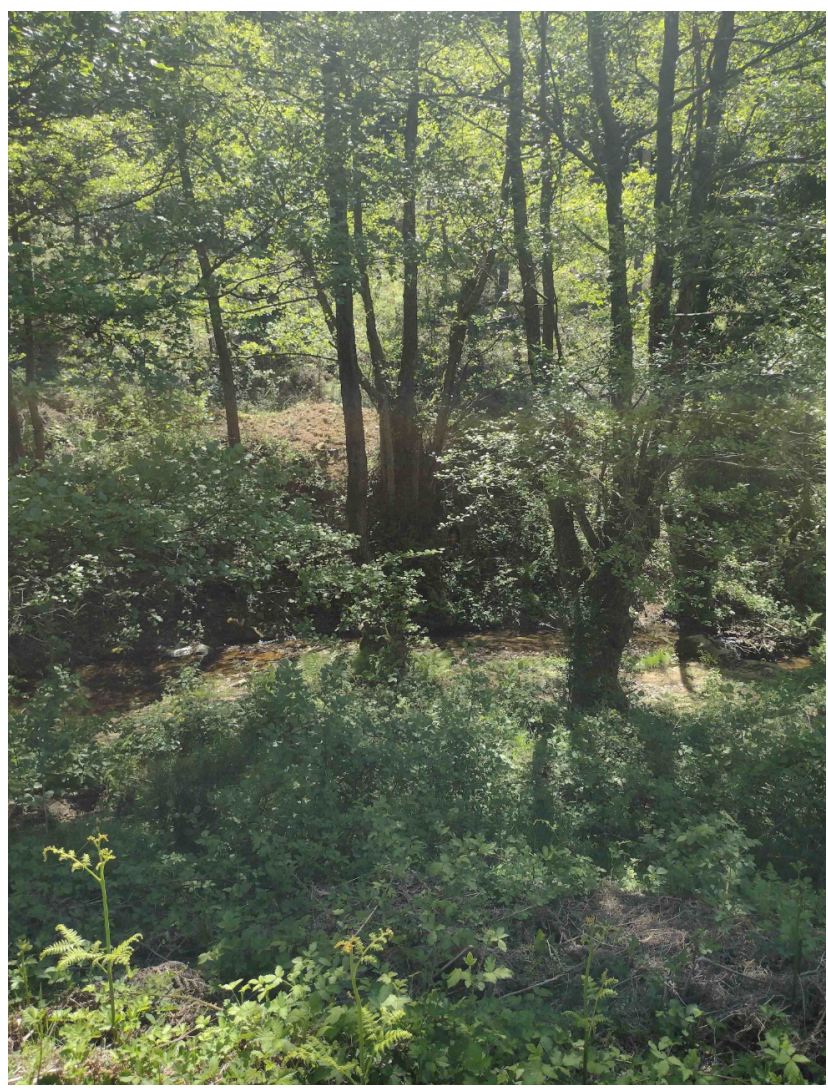

Fig. 9. Small stream near Kremen Village.

habitat preferences. International Journal of Dipterological Research 21 (3): 179-182.

Kechev M. 2019 Predatory flies of the family Dolichopodidae (Diptera: Empidoidea) from forest and riparian habitats in Bulgaria. Proceedings papers 150 years of Bulgarian Academy of Sciences, Forest Research Institute, Bulgarian Academy of Sciences, 2019, pp. 47-54.

Kechev M. 2021 Diversity of long-legged flies (Diptera, Dolichopodidae) of the Balkan Mountains (Bulgaria and Serbia). Historia naturalis bulgarica 42: 15-24.

https://doi.org/10.48027/hnb.42.041

Kechev M., Glogov P. 2021 Forest Long-legged flies (Diptera: Dolichopodidae) from the park of the Forest Research Institute with new records for Bulgaria and notes on habitat affinity. Silva Balcanica 22 (1): 67-75.

https://doi.org/10.3897/silvabalcanica.22.e62052

Kechev M., Ivanova M. 2015a New records and list of known species of the family Dolichopodidae 
(Diptera, Empidoidea) from Croatia. Natura Croatica 24 (2): 323-330. https://doi.org/10.20302/NC.2015.24.22

Kechev M., Ivanova, M. 2015b New records of Dolichopodidae (Diptera) from Bulgaria. Comparison of dolichopodid diversity on river banks and in some forests of the Upper Thracian Plain. Silva Balcanica 16 (1): 87-104.

Kechev M., Naglis S., Tonguç A., Pollet M. 2020 Checklist of the Dolichopodidae (Diptera, Empidoidea) of the Balkan Peninsula, with first records for Bulgaria, Montenegro, North Macedonia, and for the European part of Turkey. Zootaxa 4819 (3): 436-472.

https://doi.org/10.11646/zootaxa.4819.3.2

Naglis S. 2017 A new species of Systenus Loew (Diptera, Dolichopodidae) from Croatia. Alpine entomology 1: 39-41.

https://doi.org/10.3897/alpento.1.20462
Negrobov O., Naglis S. 2016 Palaearctic species of the genus Medetera (Diptera: Dolichopodidae). Zoosystematica rossica 25 (2): 333-379.

Negrobov O., Stackelberg A.A. 1969 Dolichopodidae. In: Stackelberg A.A., Narchuk E.P. (eds) Opredelitel nasekomyh Evropejskoj chasti SSSR., T. 5, Ch. 1: Dvukrylye, blokhi. Nauka, Leningrad, pp. 670-752. (In Russian)

Parent O. 1938 Diptères Dolichopodidés. Faune de France 35: 1-720.

Pollet M., Ivković M. 2018 Dolichopodidae of riverbeds and springs in Croatia with an updated checklist of Croatia (Diptera). Zootaxa 4455 (3): 401-428.

https://doi.org/10.11646/zootaxa.4455.3.1 